\author{
M. Velikaya, N. Sheveleva, I. Tishchenko
}

National University of Pharmacy, Kharkiv

\title{
PATHOGENETIC ASPECTS OF HYPOLIPIDEMIC DRUGS ANTIMICROBIAL POTENTIAL IN METABOLIC SYNDROME THERAPY: A THEORETICAL STUDY
}

Topicality. Metabolic syndrome (MS) is an extremely common medical and social problem. However, there is no modern understanding of the MS ethiopathogenetic mechanisms. Debates about MS discuss different versions of the development of this symptom complex, when each of the clusters can be primary in the pathogenesis of MS. Therefore, any metabolic processes disorders in the human body are always accompanied with and lead to a changes in quantitative and qualitative microbiocenoses composition, and vice versa, microbiota imbalance may induce the development of pathological states including MS.

Aim. To analyze the published data that concern antimicrobial potential of modern drugs with lipid-lowering properties used in complex therapy of MS.

Materials and methods. Lipid-lowering agents and their direct or indirect antimicrobial effect may cause the microbiota imbalance in the human body. While studying the data, we analyzed antimicrobial potential of modern drugs with lipid-lowering properties used in complex therapy of MS. We studied recent research in the field of microecology and the results of significant effect in normal microflora on metabolic processes.

Results and discussion. According to modern concepts, an important pathogenetic link in the obesity and MS development is the imbalance in normal intestinal microflora. At the same time, lipid-lowering agents can have a direct or indirect antimicrobial effect and, consequently, cause an imbalance of microbiota in the human body. Thereby, it is important for the therapy effectiveness to take into account the significant antimicrobial potential of drugs used in the correction of metabolic disorders.

Conclusions. The future complex antimicrobial properties study of drugs used in the correction of described pathological states has a good perspective.

Key words: metabolic syndrome; antimicrobial activity; dyslipidemia

\section{М. М. Велика, Н. Ю. Шевельова, І. Ю. Тищенко}

Патогенетичні аспекти антимікробного потенціалу гіполіпідемічних препаратів у терапії метаболічного синдрому: теоретичне дослідження

Актуальність. На теперішній час метаболічний синдром (MC) $є$ надзвичайно поширеною медичною і соціальною проблемою. Однак єдиного розуміння етіопатогенетичних механізмів розвитку МС немає. Обговорюються різні версії розвитку цього симптомокомплексу, де кожен з кластерів може бути первинним у патогенезі MC. Між іншим, будь-які порушення метаболічних процесів організму людини завжди супроводжуються і призводять до зміни кількісного і якісного складу мікробіоценозів, і навпаки, дисбаланс мікробіоти може індукувати розвиток патологічних станів, зокрема і при МС.

Мета роботи. Огляд присвячений аналізу літературних даних про наявність антимікробного потенціалу у сучасних препаратів з гіполіпідемічними властивостями, які використовуються в комплексній терапії метаболічного синдрому.

Результати та їх обговорення. Відповідно до сучасних уявлень важливою патогенетичною ланкою в розвитку ожиріння і метаболічного синдрому є порушення нормальної мікрофлори кишечника. А гіполіпідемічні засоби можуть надавати прямий або опосередкований антимікробний ефект , а отже, викликати дисбаланс мікробіоти в організмі людини. Тому облік значимого антимікробного потенціалу препаратів, що використовуються в корекції метаболічних порушень, має важливе значення для ефективності проведеної терапії.

Висновки. Планування вивчення комплексного антимікробного потенціалу препаратів, що використовуються в корекції метаболічного синдрому, є перспективним.

Ключові слова: метаболічний синдром; антимікробна активність; дисліпідемії

М. М. Великая, Н. Е. Шевелева, И. Ю. Тищенко

Патогенетические аспекты антимикробного потенциала гиполипидемических препаратов в терапии метаболического синдрома: теоретическое исследование

Актуальность. В настоящее время метаболический синдром (МС) является чрезвычайно распространенной медицинской и социальной проблемой. Однако единого понимания этиопатогенетических механизмов развития МС нет. Обсуждаются различные версии развития этого симптомокомплекса, где каждый из кластеров может быть первичным в патогенезе МС. Между тем, любые нарушения метаболических процессов организма человека всегда сопровождаются и приводят к изменению количественного и качественного состава микробиоценозов, и наоборот, дисбаланс микробиоты может индуцировать развитие патологических состояний, в том числе и при МС.

Цель работы. Обзор посвящен анализу литературных данных о наличии антимикробного потенциала у современных препаратов с гиполипидемическими свойствами, используемых в комплексной терапии метаболического синдрома. 
Результаты и их обсуждение. Согласно современным представлениям важным патогенетическим звеном в развитии ожирения и метаболического синдрома является нарушение нормальной микрофлоры кишечника. А гиполипидемические средства могут оказывать прямой или опосредованный антимикробный эффект и, следовательно, вызывать дисбаланс микробиоты в организме человека. И учет значимого антимикробного потенциала препаратов, использующихся в коррекции метаболических нарушений, имеет важное значение для эффективности проводимой терапии.

Выводы. Планирование изучения комплексного антимикробного потенциала препаратов, использующихся в коррекции метаболического синдрома, является перспективным.

Ключевые слова: метаболический синдром; антимикробная активность; дислипидемии

\section{INTRODUCTION}

Metabolic syndrome (MS) is defined as a complex of dynamic metabolic disorders and hormonal balance of the body. Today, MS is an extremely common medical and social problem. World Health Organization (WHO) experts note an increase in the incidence of MS among people in many countries around the world: in Western Europe, Australia and the United States the MS prevalence is on average 25-35\%, in China the incidence of MS has reached epidemiological proportions [1, 2, 3]. In addition, if earlier MS was considered a "disease" of the elderly, now this state is registered in young people, including children $[4,5]$. The MS prevalence depends on sex, age, ethnicity and the diagnostic criteria used, and its highest occurrence is observed in economically developed countries [6, 7]. The criteria for MS are abdominal obesity, hypertension, lipid spectrum alterations, and carbohydrate metabolism disorders $[8,9]$.

However, at present there is no common understanding of the ethiopathogenetic mechanisms of MS development. Therefore, much attention is paid to study of the reasons that caused MS. Most often insulin resistance (IR) is indicated as a primary pathogenetic mechanism $[10,11]$. Also, in recommendations of WHO (1998), European Group for the Study of Insulin Resistance (EGIR, 1999) and American Association of Clinical Endocrinologists (AACE, 2003) IR was identified as the main component of MS. However, a number of researchers consider obesity to be the main link in the MS pathogenesis $[11,12]$. In addition, the leading role of arterial hypertension and lipid metabolism disorders in the MS pathogenesis is not excluded $[13,16]$. There are a number of studies showing that dyslipidemia can be a predictor of MS development, and lipid metabolism in the form of deficiency in polyunsaturated fatty acid cells is the cause of the IR development $[14,15,16]$. Debates about MS discuss different versions of the development of this symptom complex, when each of the clusters can be primary in the pathogenesis of MS $[17,18]$.

Recent research in the field of microecology demonstrates a significant effect of normal microflora on metabolic processes. Microorganism metabolites can be effectors, cofactors and signal molecules that regulate the rate and severity of metabolic reactions both in normal and in pathological processes $[19,20]$. In addition, the microbiological model has changed today- unicellular microorganisms are considered as integral microbial associations, representing a separate organ - microbiota [21].
And the relationship "the human body - the intestinal microbiota" is evaluated as a single macroecological system of the body. Therefore, any metabolic processes disorders in the human body are always accompanied with and lead to a changes in the quantitative and qualitative microbiocenoses composition, and vice versa, imbalance of the microbiota can induce the development of pathological states including MS.

One of the factors that caused the changes in human microbiota is the repeated and repeated effects of various antibacterial drugs, especially in industrially developed countries [22, 23], which correlates with the prevalence of pathological changes in MS. Because of these states polyethiologic nature, medicinal preparations of various pharmacological groups are used to their pharmacological correction. The drugs that used have a number of side effects, the development mechanisms of which in most cases have not steel explained and can be directly or indirectly related to the antimicrobial activity of these drugs. We previously identified possible antimicrobial effects in individual groups of drugs used in the treatment of type 2 diabetes mellitus, as in one of the main disorders of carbohydrate metabolism in MS [24].

The aim is to analyze the antimicrobial potential of modern drugs with lipid-lowering properties used in the MS complex therapy. Currently, the following groups of drugs are used to hyperlipidemia pharmacological correction: 3-hydroxy-3-methylglutaryl-coenzyme A-reductase inhibitors (statins), bile acid sequestrants (BAS), fibrolic acid derivatives, nicotinic acid and omega- 3 polyunsaturated fatty acids (PUFAs).

\section{MATERIALS AND METHODS}

Lipid-lowering agents and their direct or indirect antimicrobial effect may cause the microbiota imbalance in the human body. While studying the data, we analyzed antimicrobial potential of modern drugs with lipid-lowering properties used in complex therapy of MS. We studied recent research in the field of microecology and the results of significant effect in normal microflora on metabolic processes.

\section{RESULTS AND DISCUSSION}

Statins are steel remained unconditional leader among drugs for the dyslipidemia treatment [25]. The statins mechanism of action is associated with competitive inhibition of the enzyme - hydroxymethylglutaryl-CoA re- 
ductase (HMG-CoA reductase), which catalyzes the cholesterol synthesis in the liver cells, as well as the reflex increase in the receptors for low-density lipoprotein (LDL) in the liver. Thus, the amount of LDL in the blood plasma decreases. Statins also inhibit the absorption of exogenous cholesterol (ingested with food) in the intestine. In addition to hypolipidemic action, statins have a direct effect on the vascular wall, which is manifested in improving the endothelium functional state, reducing the severity of inflammation and slowing down the formation of thrombus. Thus, statins are the first choice drugs in patients with cardiac ischemia, hyperlipidemia/dyslipidemia and a high risk of coronary or cerebral complications [26]. Complications associated with the use of statins, studied well enough. The most dangerous are myopathies and rhabdomyolysis. In addition, some patients have statininduced changes in the central nervous system, manifested as headaches, insomnia, dizziness, fatigue. However, first of all, the side effects of statin therapy are associated with the gastrointestinal tract - dyspepsia, abdominal pain, diarrhea, nausea, exacerbation of gastrointestinal diseases, anorexia, pancreatitis, cholestatic jaundice, increased liver transaminases several times.

Natural statins - lovastatin and compactin are formed by mycelial fungi, representatives of the genera Aspergillus, Penicillium, Paecilomyces, Trichoderma, Hypomyces, Phoma, Deratomyces, Gymnoascus and Menascus [27]. Taking into account their nature, it can be assumed that they have an antibacterial effect. And, indeed, recently there were publications in which the presence of direct antibacterial action on gram-positive and on gram-negative microorganisms in vitro is proved [28]. Statins such as simvastatin, atorvastatin, rosuvastatin, and fluvastatin have demonstrated a bacteriostatic effect against Grampositive Staphylococcus spp., Streptococcus spp., Enterococcus spp., and bacteria of the genus Bacillus and Gramnegative Pseudomonas aeruginosa, Acinetobacter spp., Klebsiella pneumonia, Proteus spp. [28]. In addition, simvastatin has shown its bactericidal action against bacteria of the genus Moraxella and Borrelia [28]. An in vivo study in mice showed that adding simvastatin to the regimen significantly reduced the time needed to cure tuberculosis infection and reduced the relapse rate to $20 \%$ after 3.5 months of treatment [29]. However, the mechanism of statins action on the bacterial cell is still unclear, and an active search for an answer to this question is currently underway. But the presence of a direct antibacterial effect indicates the ability to cause changes in the intestinal microflora and the gastrointestinal tract functional disorders.

Fibrolic acid derivatives - fibrates - stimulate peroxisome proliferation and activate peroxisome enzymes, transmitting the signal to the gene level through a specific receptor - peroxisome proliferator-activated receptor alpha (PPARa), which is a transcription factor. This leads to the lipoprotein lipase activation that increases the very-low-density lipoprotein (VLDL) breakdown. In addition, fibrates reduce the formation of triglycerides and apolipoprotein B. Fibrates have the ability to enhance the hypoglycemic drugs action that gives them an advantage in treating hyperlipidemia in patients with diabetes mellitus. By lowering the level of triglycerides, fibrates cause local anti-inflammatory effect in the vascular wall affected by the atherosclerotic process, inhibiting the production anti-inflammatory substances by macrophages and as a consequence inhibit atherogenesis. Side effects of their use include: dyspeptic disorders such as abdominal pain, nausea, vomiting, diarrhea and flatulence, moderate allergic reactions, leukopenia, as well as increased hepatic enzymes activity and cholelithiasis. While we study the question of the possible antimicrobial effect of fibrates, we encountered single publications on the activity of fenofibric acid and clofibrate against eukaryotes [30,31]. Apparently, this effect is associated with the ability of fibrates to inhibit the intracellular lipid molecules transfer. Along with this, in the scientific literature there is no information on the direct antibacterial activity of fibrates, however, taking into account the above-mentioned effects, one can assume their negative effect on the normomicrobiocenosis of the intestine.

Bile acid sequestrants (ion exchange resins) are used as second-line drugs in combined therapy with statins to obtain an additional effect at a high level of cholesterol-LDL (LDL-Ch). BAS disrupt bile salts enterohepatic circulation. Bile acid recycling interruption increased excretion with feces and depletion of cholesterol in the liver all these mechanisms lead to an increase in the expression of LDL receptors in hepatocytes, which in turn leads to a decrease in the blood plasma cholesterol level. BAS continuous administration stimulates the reductase HMG-CoA activity (secondary effect), so they are often combined with statins. Their side effects are mainly due to the fact that they in the intestine adsorb not only bile acids but also some digestive enzymes (digestion, bloating, heartburn, flatulence and liquid stool may be alterated). Longterm administration of BAS high doses can also disrupt the absorption of fat-soluble vitamins (A, D, E), folic acid and other medications taken. However, the binding of fatty acid (FA) salts may inhibit their antimicrobial action and can cause excessive bacterial growth and lead to the microecological abnormalities development. The normoflora influence on fat metabolism, metabolism of FA salts, cholesterol, glucose, energy homeostasis is well-known. Therefore, there is a necessity of special studies on the BAS therapy effect on the intestinal microflora composition [32].

Like bile acid sequestrants, nicotinic acid is a traditional lipid-lowering drug and is used for about 35 years. Nicotinic acid in lipid-lowering doses suppresses the free fatty acids (FFA) release from adipose tissue adipocytes and accordingly lowers their plasma concentration, which is accompanied by a decrease in the total amount of synthesized cholesterol-VLDL (VLDL-Ch) and apo-B. Because LDL-Ch is formed as a result of VLDL catabolism, a decrease 
in the amount of cholesterol produced by the VLDL-Ch can be accompanied by a decrease in plasma LDL-Ch concentrations of and total cholesterol. In addition to this mechanism, the main ways to reduce the concentration of triglyceride (TG) can be nicotinic acid mediated suppression of de novo lipogenesis, as well as suppression of the esterification process, i.e. formation of TG from FA in hepatocytes. It was recently found that nicotinic acid not only normalizes the lipoprotein exchange, but also affects the immune system cells by stimulating their receptor - G protein-coupled receptor (GPR)109A activity and this leads to a decrease in the intensity of the vascular sclerosis inflammatory component [33]. Serious complications of nicotinic acid administration include impaired liver function and increased blood glucose level. Another relatively frequent group of side effects are gastrointestinal: nausea, diarrhea, less often - heartburn, vomiting, increased or decreased appetite. Taking into account the above, we can assume the effect of nicotinic acid on the autoflora of the intestine.

Thus, lipid-lowering agents have different mechanisms of action, differ in pharmacodynamic and pharmacokinetic parameters, and some of them, according to the type of cell-receptor interaction and the chemical nature, can have a direct or indirect antimicrobial effect and, consequently, cause a microbiota imbalance in the human body.

Recently, numerous scientific reports have reported the possible role of intestinal normoflora in the obesity and MS pathogenesis $[34,35]$. It has been experimentally proved that the degree of severity of microbiota alterations correlates with the excess body weight indices, and in people with excess body weight, the total metabolic activity of obligate microorganisms has decreased [36]. It was shown that food with a high fat content caused an increase in the proportion of intestinal Gram-negative microbiota, thus contributing to an increase in the bacterial lipopolysaccharides intestinal absorption. And this led to the "metabolic endotoxemia" development as one of the factors of the obesity progress [35].

In addition, one of the main microflora functions is the carbohydrate utilization. As is known, the main end products of indigestible carbohydrate fermentation are short-chain fatty acids (SHFAs), which are an energy substrate for many body tissues. SHFAs are not only directly participate in energy metabolism, but also perform a signal function by activating GPRs. Thus, GPR43 is expressed in most cells of the gastrointestinal tract, as well as in adipose tissue and immune cells. And the activation of this receptor enhances the immune response against the intestinal pathogenic flora [37]. GPR41 is expressed in neuroendocrine L-cells and sympathetic ganglion cells [38]. It was experimentally shown that activation of this receptor led to energy expenditure in laboratory animals, which confirms the participation of SHFAs in maintaining the energy homeostasis in the body.

It is interesting that in non-microbial animals much more cholesterol is accumulated in the liver than in the control group, the bile FA concentration increased in several times, and the cholesterol absorption also increased by not less than in 25\% [39]. Moreover, recent studies have shown that the presence of microflora is necessary for the FA metabolic effects development.

\section{CONCLUSIONS}

Thus, an important pathogenic link in the obesity and MS development is the normal intestinal microflora imbalance. In turn, metabolic disorders lead to an imbalance of dynamic equilibrium in the macro-organism-microorganism system. From these positions, it is interesting not only to study the possible antimicrobial effect of individual drugs, but also to analyze the possible interaction of different pharmacological drug groups concerning antimicrobial potential. Despite this, we have not seen any data about such studies. However, it is important to consider the significant antimicrobial potential of drugs used for the metabolic disorders correction in order to increase the therapy effectiveness. The future complex antimicrobial properties study of drugs used in the correction of described pathological states has a good perspective.

Conflict of Interests: authors have no conflict of interests to declare.

\section{REFERENCES}

1. Cameron, A. J. The metabolic syndrome : prevalence in worldwide populations / A. J. Cameron, J. E. Shaw, P. Z. Zimmet // Endocrinol. Metab. Clin North Am. - 2004. - Vol. 33, Issue 2. - P. 351-375. doi: 10.1016/j.ecl.2004.03.005

2. Prevalence of metabolic syndrome among urban community residents in China / G. R. Wang, L. Li, Y. Y. Pan et al. // BMC Public Health. - 2013. Vol. 13, Issue 1. - 599 p. doi: 10.1186/1471-2458-13-599

3. The prevalence of metabolic syndrome and metabolically healthy obesity in Europe : a collaborative analysis of ten large cohort studies / J. V. van Vliet-Ostaptchouk, M. L. Nuotio, S. N. Slagter et al. // BMC Endocrine Disorders. - 2014. - Vol. 14, Issue 1. - 9 p. doi: 10.1186/1472-6823-14-9

4. Сергеев, В. В. Метаболический синдром : причины, лечение и профилактика / В. В. Сергеев // Врач. - 2009. - № 2. - С. 36-41.

5. Prevalence and sociodemographic correlates of metabolic syndrome in school-aged children and their parents in nine Mesoamerican countries / E. Villamor, C. C. Finan, M. Ramirez-Zea, A. V. Roman // Public Health Nutrition. - 2016. - Vol. 20, Issue 2. - P. 255-265. doi: 10.1017/S1368980016002342

6. Grundy, S. M. Metabolic syndrome update / S. M. Grundy // Trends in Cardiovascular Medicine. - 2016. - Vol. 26, Issue 4. - P. 364-373.

7. Kaur, J. A comprehensive review on metabolic syndrome / J. Kaur // Cardiol. Res. and Practice. - 2014. - P. 1-21. doi: 10.1155/2014/943162

8. Diagnosis and management of the metabolic syndrome / S. M. Grundy, J. I. Cleeman, S. R. Daniels et al. // Circulation. - 2005. - Vol. 112, Issue 17. P. 2735-2752. doi: 10.1161/CIRCULATIONAHA.105.169404

9. Day, C. Diagnostic definitions-metabolic syndrome / C. Day // The British J. of Diabetes. Vascular Disease. - 2005. - Vol. 5, Issue 3. - P. 115-118. doi: $10.1177 / 14746514050050030101$ 
10. Guo, S. Insulin signaling, resistance, and metabolic syndrome: insights from mouse models into disease mechanisms / S. Guo // J. of Endocrinol. 2014. - Vol. 220, Issue 2. - P. T1-T23. doi: 10.1530/JOE-13-0327

11. Ройтберг, Г. Е. Роль инсулинорезистентности в диагностике метаболического синдрома / Г. Е. Ройтберг, Т. И. Ушакова, Ж. В. Дорош // Кардиол. - 2004. - № 3. - С. 94-101.

12. Reaven, G. M. The individual components of the metabolic syndrome : is there a raison d'Etre? / G. M. Reaven // J. Am. Coll. Nutr. - 2007. - Vol. 26, Issue 3. - P. 191-195. doi: 10.1080/07315724.2007.10719601

13. Чазова, И. Е. Метаболический синдром / И. Е. Чазова, В. Б. Мычка. - М. : Медиа Медика, 2008. - 319 с.

14. Гинзбург, М. М. Ожирение. Влияние на развитие метаболического синдрома. Профилактика и лечение / М. М. Гинзбург, Н. Н. Корюков. М. : Медпрактика, 2002. - С. 23-25.

15. Ikewaki, K. Dyslipidemia in metabolic syndrome / K. Ikewaki, J. Tohyama // Nihon Rinsho. Japanese J. of Clinical Medicine. - 2004. - Vol. 62, Issue 6. P. 1099-1103.

16. Devi, S. A. Dyslipidemia in Metabolic Syndrome : an Overview of Lipoprotein-Related Disorders / S. A. Devi // Intern. J. of Cardiol. and Lipidol. Res. - 2017. - Vol. 4, Issue 1. - P. 6-15. doi: 10.15379/2410-2822.2017.04.01.02

17. Метаболический синдром : больше вопросов, чем ответов / С. М. Чибисов, С. И. Рапопорт, Д. Б. Колесников и др. // Клин. мед. - 2008. № 6. - C. 30-35.

18. Grundy, S. M. Metabolic syndrome update / S. M. Grundy // Trends in Cardiovascular Medicine. - 2016. - Vol. 26, Issue 4. - P. 364-373. doi: $10.1016 /$ j.tcm.2015.10.004

19. Shenderov, B. A. Probiotics and functional foods. Food Engineering. [Eds UNESCO-EOLSS Joint Committee], in Encyclopedia of Life Support Systems (EOLSS). - Oxford, UK : Developed under the Auspices of the UNESCO, EOLSS Publishers, 2011.

20. Topping, D. L. Shot-chain fatty acids and human colonic function : roles of resistant starch and nonstarch polysaccharides / D. L. Topping, P. M. Clifton // Physiol. Rev. - 2001. - Vol. 81, Issue 3. - P. 1031-1064.

21. Симбионтное пищеварение в свете теории А. М. Уголева о пищеварительно-транспортном конвейере / А. И. Парфенов, В. В. Чернин, В. М. Бондаренко и др. // Русс. мед. журн. - 2014. - Т. 22, № 15. - С. 1088-1092.

22. Wilson, I. D. Gut microbiome interactions with drug metabolism, efficacy, and toxicity / I. D. Wilson, J. K. Nicholson // Translational Res. - 2017. Vol. 179. - P. 204-222. doi: 10.1016/j.trsl.2016.08.002

23. Current understanding of dysbiosis in disease in human and animal models / A. K. DeGruttola, D. Low, A. Mizoguchi, E. Mizoguchi // Inflammatory Bowel Dis. - 2016. - Vol. 22, Issue 5. - 1137 p. doi: 10.1097/MIB.0000000000000750

24. Великая, М. М. Микробиологические аспекты некоторых эндокринных патологий / М. М. Великая, Н. Е. Шевелева // Укр. біофармац. журн. - 2010. - № 4 (9). - С. 6-12.

25. Ghose, T. Statins in Dyslipidemia : Handbook of Lipidology / T. Ghose. - 2016. - 105 p.

26. Творогова, М. Г. Статины - механизм действия и плейотропные эффекты / М. Г. Творогова, Е. Ю. Самойленко, В. Г. Наумов // Лабораторная медицина. - 2008. - № 9. - С. 7-11.

27. Плеотропный эффект статинов, образуемых мицелиальными грибами / Н. А. Баранова, В. Г. Крейер, А. А. Осмоловский и др. // Иммунопатол., аллергол., инфектол. - 2010. - Т. 1. - С. 240.

28. Is there potential for repurposing statins as novel antimicrobials? / E. Hennessy, C. Adams, F. J. Reen, F. O’Gara // Antimicrobial Agents and Chemotherapy. - 2016. - Vol. 60, Issue 9. - P. 5111-5121. doi: 10.1128/AAC.00192-16

29. Statin adjunctive therapy shortens the duration of TB treatment in mice / N. K. Dutta, N. Bruiners, M. L. Pinn et al. // J. of Antimicrobial Chemotherapy. - 2016. - Vol. 71, Issue 6. - P. 1570-1577. doi: 10.1093/jac/dkw014

30. Wong, R. P. In vitro antimalarial activity and drug interactions of fenofibric acid / R. P. Wong, T. M. Davis // Antimicrobial Agents and Chemotherapy. - 2012. - Vol. 56, Issue 6. - P. 2814-2818. doi: 10.1128/AAC.05076-11

31. Madhosingh, C. Antimicrobial effects of clofibrate on the wheat pathogen Fusarium culmorum / C. Madhosingh, W. Orr // J. of Environmental Sci. \& Health Part B. - 1981. - Vol. 16, Issue 5. - P. 587-604. doi: 10.1080/03601238109372281

32. Out, C. Bile acid sequestrants : more than simple resins / C. Out, A. K. Groen, G. Brufau // Current Opinion in Lipidol. - 2012. - Vol. 23, Issue 1. P. 43-55. doi: 10.1097/MOL.0b013e32834f0ef3

33. Nicotinic acid inhibits progression of atherosclerosis in mice through its receptor GPR109A expressed by immune cells / M. Lukasova, C. Malaval, A. Gille et al. // J. Clin. Invest. - 2011. - Vol. 121, Issue 3. - P. 1163-1173. doi: 10.1172/JCI41651

34. Курмангулов, А. А. Функциональная активность микробиоты кишечника при метаболическом синдроме / А. А. Курмангулов, Е. Ф. Дороднева, Д. Н. Исакова // Ожирение и метаболизм. - 2016. - № 1. - С. 16-19.

35. Gut microbiota and metabolic syndrome / D. Festi, R. Schiumerini, L. H. Eusebi et al. // World J. Gastroenterol. - 2014. - Vol. 20, Issue 43. P. 16079-16094. doi: 10.3748/wjg.v20.i43.16079

36. Захаренко, С. М. Инфекции, микробиота кишечника человека и метаболический синдром / С. М. Захаренко, Ю. А. Фоминых, С. Н. Мехтиев // Эффективная фармакотерапия. - 2011. - № 7. - С. 14-22.

37. G protein-coupled receptor 43 is essential for neutrophil recruitment during intestinal inflammation / C. Sina, O. Gavrilova, M. Förster et al. // The J. of Immunol. - 2009. - Vol. 183, Issue 11. - P. 7514-7522. doi: 10.4049/jimmunol.0900063

38. Short-chain fatty acids and ketones directly regulate sympathetic nervous system via G protein-coupled receptor 41 (GPR41) / I. Kimura, D. Inoue, T. Maeda et al. // Proceedings of the National Academy of Sci. - 2011. - Vol. 108, Issue 19. - P. 8030-8035. doi: 10.1073/pnas.1016088108 39. Wostmann, B. S. Intestinal bile acids and cholesterol absorption in the germfree rat / B. S. Wostmann // J. Nutr. - 1973. - Vol. 103, Issue 7. - P. 982- 990.

\section{REFERENCES}

1. Cameron, A. J., Shaw, J. E., Zimmet, P. Z. (2004). The metabolic syndrome: prevalence in worldwide populations. Endocrinology and Metabolism Clinics of North America, 33 (2), 351-375. doi: 10.1016/j.ecl.2004.03.005

2. Wang, G. R., Li, L., Pan, Y. H. et al. (2013). Prevalence of metabolic syndrome among urban community residents in China. BMC Public Health, 13 (1), 599. doi: 10.1186/1471-2458-13-599

3. Van Vliet-Ostaptchouk, J. V., Nuotio, M-L., Slagter, S. N. et al. (2014). The prevalence of metabolic syndrome and metabolically healthy obesity in Europe: a collaborative analysis of ten large cohort studies. BMC endocrine disorders, 14 (1), 9. doi: 10.1186/1472-6823-14-9

4. Sergeev, V. V. (2009). Vrach, 2, 36-41.

5. Villamor, E., Finan, C. C., Ramirez-Zea, M., Roman, A. V. (2016). Prevalence and sociodemographic correlates of metabolic syndrome in schoolaged children and their parents in nine Mesoamerican countries. Public Health Nutrition, 20 (2), 255-265. 
6. Grundy, S. M. (2016). Metabolic syndrome update. Trends in cardiovascular medicine, 26 (4), 364-373.

7. Kaur, J. (2014) A comprehensive review on metabolic syndrome. Cardiology research and practice, 1-21. doi: 10.1155/2014/943162

8. Grundy, S. M., Cleeman, J. I., Daniels, S. R. et al. (2005). Diagnosis and management of the metabolic syndrome. Circulation, 112 (17), $2735-2752$. doi: 10.1161/CIRCULATIONAHA.105.169404

9. Day, C. (2005). Diagnostic definitions-metabolic syndrome. The British Journal of Diabetes. Vascular Disease, 5 (3), 115-118. doi: $10.1177 / 14746514050050030101$

10. Guo, S. (2014). Insulin signaling, resistance, and metabolic syndrome: insights from mouse models into disease mechanisms. Journal of Endocrinology, 220 (2), T1-T23. doi: 10.1530/JOE-13-0327

11. Roitberg, G. E., Ushakova, T. I., Dorosh, Zh. V. (2004). Kardiologiia, 3, 94-101.

12. Reaven, G. M. (2007). The individual components of the metabolic syndrome: is there a raison d'Etre? J.Am.Coll. Nutr., 26, 3, 191-195. doi: 10.1080/07315724.2007.10719601

13. Chazova, I. E., Mychka, V. B. (2008). Metabolicheskii sindrom. Moscow: Media Medika, 319

14. Ginzburg, M. M., Koriukov, N. N. (2002). Ozhirenie. Vliianie na razvitie metabolicheskogo sindroma. Profilaktika i lechenie. Moscow: Medpraktika, 23-25. 15. Ikewaki, K., Tohyama, J. (2004). Dyslipidemia in metabolic syndrome. Nihon rinsho. Japanese journal of clinical medicine, 62 (6), 1099-1103.

16. Devi, S. (2017). Dyslipidemia in Metabolic Syndrome: an Overview of Lipoprotein- Related Disorders. International Journal of Cardiology and Lipidology Research, 4 (1). doi: 10.15379/2410-2822.2017.04.01.02

17. Chibisov, S. M., Rapoport, S. I., Kolesnikov, D. B. et al. (2008). Klinicheskaia meditcina, 6, 30-35.

18. Grundy, S. M. (2016). Metabolic syndrome update. Trends in cardiovascular medicine, 26 (4), 364-373. doi: 10.1016/j.tcm.2015.10.004

19. Shenderov, B. A. (2011). Probiotics and functional foods. Food Engineering. [Eds UNESCO-EOLSS Joint Committee], in Encyclopedia of Life Support Systems (EOLSS). Oxford, UK: Developed under the Auspices of the UNESCO, EOLSS Publishers.

20. Topping, D. L., Clifton, P. M. (2001). Shot-chain fatty acids and human colonic function: roles of resistant starch and nonstarch polysaccharides. Physiological reviews, 81 (3), 1031-1064.

21. Parfenov, A. I., Chernin, V. V., Bondarenko, V. M. et al. (2014). Russkii meditcinskii zhurnal, 22 (15), 1088-1092.

22. Wilson, I. D., Nicholson, J. K. (2017). Gut microbiome interactions with drug metabolism, efficacy, and toxicity. Translational Research, 179, $204-222$. doi: $10.1016 /$ j.trsl.2016.08.002

23. DeGruttola, A. K., Low, D., Mizoguchi, A., Mizoguchi, E. (2016). Current understanding of dysbiosis in disease in human and animal models. Inflammatory bowel diseases, 22 (5), 1137. doi: 10.1097/MIB.0000000000000750

24. Velikaia, M. M., Sheveleva, N. E. (2010). Ukrainskyi biofarmatsevtychnyi zhurnal - Ukrainian biopharmaceutical journal, 4 (9), 6 - 12.

25. Ghose, T. (2016). Statins in Dyslipidemia: handbook of Lipidology, 105.

26. Tvorogova, M. G., Samoilenko, E. Yu., Naumov, V. G. (2008). Laboratornaia meditcina, 9, 7-11.

27. Baranova, N. A., Kreier, V. G., Osmolovskii, A. A. et al. (2010). Immunopatologiia, allergologiia, infektologiia, 1, $240-240$.

28. Hennessy, E., Adams, C., Reen, F.J., O'Gara, F. (2016). Is there potential for repurposing statins as novel antimicrobials? Antimicrobial Agents and Chemotherapy, 60 (9), 5111-5121. doi: 10.1128/AAC.00192-16

29. Dutta, N. K., Bruiners, N., Pinn, M. L. et al. (2016). Statin adjunctive therapy shortens the duration of TB treatment in mice. Journal of Antimicrobial Chemotherapy, 71 (6), 1570-1577. doi: 10.1093/jac/dkw014

30. Wong, R. P., Davis, T. M. (2012). In vitro antimalarial activity and drug interactions of fenofibric acid. Antimicrobial agents and chemotherapy, 56 (6), 2814-2818. doi: 10.1128/AAC.05076-11

31. Madhosingh, C., Orr, W. (1981). Antimicrobial effects of clofibrate on the wheat pathogen Fusarium culmorum. Journal of Environmental Science \& Health Part B, 16 (5), 587-604. doi: 10.1080/03601238109372281

32. Out, C., Groen, A.K., Brufau, G. (2012). Bile acid sequestrants: more than simple resins. Current opinion in lipidology, 23 (1), 43-55. doi: 10.1097/ MOL.0b013e32834f0ef3

33. Lukasova, M., Malaval, C., Gille, A. et al. (2011). Nicotinic acid inhibits progression of atherosclerosis in mice through its receptor GPR109A expressed by immune cells. J. Clin. Invest., 121 (3), 1163-1173. doi: 10.1172/JCI41651

34. Kurmangulov, A. A., Dorodneva, E. F., Isakova, D. N. (2016). Ozhirenie i metabolism, 1, 16-19.

35. Festi, D., Schiumerini, R., Eusebi, L. H. et al. (2014). Gut microbiota and metabolic syndrome. World J Gastroenterol, 20 (43), 16079-16094. doi: 10.3748/wig.v20.i43.16079

36. Zakharenko, S. M., Fominykh, Yu. A., Mekhtiev, S. N. (2011). Effektivnaia farmakoterapiia, 7, 14-22.

37. Sina, C., Gavrilova, O., Förster, M. et al. (2009). G protein-coupled receptor 43 is essential for neutrophil recruitment during intestinal inflammation. The Journal of Immunology, 183 (11), 7514-7522. doi: 10.4049/jimmunol.0900063

38. Kimura, I., Inoue, D., Maeda, T., Hara, T., Ichimura, A., Miyauchi, S., Tsujimoto, G. (2011). Short-chain fatty acids and ketones directly regulate sympathetic nervous system via G protein-coupled receptor 41 (GPR41). Proceedings of the National Academy of Sciences, 108 (19), $8030-8035$. doi: $10.1073 /$ pnas.1016088108

39. Wostmann, B. S. (1973). Intestinal bile acids and cholesterol absorption in the germfree rat. J. Nutr., 103 (7), $982-990$. 
Information about authors:

Velikaya M., candidate of Pharmacy, associate professor of microbiology, virusology and immunology department, National University of Pharmacy. E-mail: 7velmar@gmail.com

Sheveleva N., candidate of biological sciences, associate professor of microbiology, virusology and immunology department, National University of Pharmacy. E-mail: nsheveleva13@gmail.com

Tishchenko I., candidate of biological sciences, associate professor of microbiology, virusology and immunology department, National University of Pharmacy. E-mail: irina2okt@gmail.com

Відомості про авторів:

Велика М. М., канд. фарм. наук, доцент кафедри мікробіології, вірусології та імунології, Національний фармацевтичний університет.

E-mail: 7velmar@gmail.com

Шевельова Н. Ю., канд. биол. наук, доцент кафедри мікробіології, вірусології та імунології, Національний фармацевтичний університет.

E-mail: nsheveleva13@gmail.com

Тищенко І. Ю., канд. биол. наук, доцент кафедри мікробіології, вірусології та імунології, Національний фармацевтичний університет. E-mail: irina2okt@gmail.com

Сведения об авторах:

Великая М.М., канд. фарм. наук, доцент кафедры микробиологии, вирусологии и иммунологии, Национальный фармацевтический университет. E-mail: 7velmar@gmail.com

Шевелева Н. Е., канд. биол. наук, доцент кафедры микробиологии, вирусологии и иммунологии, Национальный фармацевтический университет. E-mail: nsheveleva13@gmail.com

Тищенко И. Ю., канд. биол. наук, доцент кафедры микробиологии, вирусологии и иммунологии, Национальный фармацевтический университет. E-mail: irina2okt@gmail.com

Рекомендовано д. біол. н., професором А. Л. Загайком Надійшла до редакції 06.06.2017 p. 